\title{
Evidence Informed Musings from The Intensive Care Unit
}

\section{Sonali Vadi* \\ Intensivist, India}

Submission: October 27, 2018; Published: October 30, 2018

*Corresponding author: Sonali Vadi, Intensivist, OV Apts, Behind Haffkine Institute, Parel, Mumbai, Maharashtra, India.

\begin{abstract}
Evidence-informed musings are derivations of bedside observations that are case and context specific. Educational significance as well as the utility of these aide memoirs for clinical judgements cannot be overemphasized. They serve as a conduit to ethical routines in applied medicine.

Keywords
\end{abstract}

Evidence-informed musings; Patient care; Rhetoric language; Teaching tools

\section{Main text}

Modern medicine is complex, abounding with challenges in clinical practice. Clinical practice can be looked at through a prism of maxims, rhetoric, or aphorisms [1], evidence-informed truisms that are backed by principles of ethics. Spectrum varies from plain observations, to humorous contemplations incorporating tangy qualities, reflecting the elements of medical practice. Functioning as an interface between decision-making and implementation, these underpin ethical professional behaviour. Analysed, these could serve to educate and guide.

\section{Decision making}

- Anticipate and accomplish electively. Corollary: It is better to perform an anticipated procedure electively rather than emergently, a time when the physiology would have gone awry to become pathological.

- Many illnesses do not have accurate answers but have approximate answers to make estimated inferences.

- $\quad$ Algorithms and protocols are meant for guidance, and not to be rigidly followed without allotting a thought to the scenario in question.

\section{Alarms}

- Alarms are aimed to alarm before they are disarmed. Tubes/Lines/Catheters

- $\quad$ Tubes and catheters are not polymeric charms. They should be removed when not needed.

\section{Medications}

- Abnormal vital signs in the critically ill augur ongoing pathology that should not be masked with medications.
- Polypharmacy is a slippery slope. Medication sideeffects and interactions are what make it so.

- Antibiotics are neither a panacea nor meant for a placebo effect.

- Daily review of medication chart for quality use of Continuation of medication $\propto$ Patient indication (i.e. medication is necessary) Psychological satisfaction of prescribing doctor

Corollary: If any medication is not necessary, it needs to be stopped.

\section{Communication}

- Communication dialogues serve as fertility moments for tangibility and credibility.

- Deficiency in communication is self-serving crisis in patient dis-satisfaction.

- $\quad$ Communicate comprehensibly.

\section{Nutrition}

- $\quad$ Food is a necessity but to feed intelligently (prescribing nutrition), an art.

\section{Documentation}

- Illegibility and writer's cramp should not be an excuse for not documenting. Type. Dictate.

\section{Miscellaneous}

- $\quad$ To assess a patient's risk, you must know your patient. This supersedes any risk calculators and statistical figures.

- Manage the patient as whole and not just individual organs. 
- When in doubt, ask. Do not assume.

- Quality of patient care is inversely proportional to the number of consultants involved in the care of a patient.

- $\quad$ Never manage any patient by a book, a book which you are not even aware of.

- Vision is 20/20 in retrospect.

- $\quad$ Everything takes longer, and costs more than you think.

Decision-making that is backed by principles of ethics positively affects patient outcomes. These would serve to teach patient care to the health care professionals.

\section{Declarations}

- Ethics approval and consent to participate: Not applicable
- $\quad$ Consent for publication: Not applicable

- Availability of data and material: Not applicable

- $\quad$ Competing interests: The author declares that she has no competing interests

- $\quad$ Funding: None

\section{References}

1. Levine D, Bleakly A (2012) Maximising medicine through aphorisms. Medical Education 46(2): 153-162.
Your next submission with Juniper Publishers will reach you the below assets

- Quality Editorial service

- Swift Peer Review

- Reprints availability

- E-prints Service

- Manuscript Podcast for convenient understanding

- Global attainment for your research

- Manuscript accessibility in different formats

( Pdf, E-pub, Full Text, Audio)

- Unceasing customer service

Track the below URL for one-step submission https://juniperpublishers.com/online-submission.php 